\title{
HIGHER EDUCATION JOURNALS: THEIR CHARACTERISTICS AND CONTRIBUTION
}

\section{Malcolm Tight}

Lancaster University, UK

m.tight@lancaster.ac.uk

\begin{abstract}
The study of higher education journals - i.e. refereed academic journals wholly focused on higher education reveals much about the field of higher education research. This analysis identified 86 such journals published in the English language, considering their focus, ownership, location, orientation, age, size and ranking. From this analysis a shorter list of 28 key journals is identified. It is argued that, given the scale of the contribution being made to higher education research - e.g. the 86 journals between them published over 16,000,000 words in 2016, with this total increasing year-on-year - it may be time to spend more effort on synthesizing and disseminating what we have already learned, rather than, or before, undertaking fresh research.
\end{abstract}




\section{Introduction}

Higher education journals are, arguably, the most important repository for the outputs of higher education research. While there are many other important outputs for higher education research - such as conference or seminar presentations, reports, monographs and books - the journal article represents the peak achievement and final word, as it will typically have been presented in other formats previously and will have gone through a peer review process to gain published status. Of course, books are also significant outputs, typically representing the equivalent of several journal articles, and we may recognise particular books as having been of seminal important to the development of the field, but, in the contemporary world of performance indicators and rankings, refereed journal articles are the gold standard.

In this article, I am limiting myself to the consideration of academic journals - and, in particular, to peer-reviewed academic journals - and will not be considering popular or professional journals (such as the Chronicle of Higher Education and Times Higher Education). This is not to deny the considerable value of such outlets, but to limit and focus the discussion. I am also limiting myself to journals published in the English language, in part because of my linguistic abilities, but also in acknowledgement of the role of English as academe's lingua franca. Many more academic journals are published in Chinese, French, German, Russian, Spanish and other languages, but they do not have the same international recognition as the leading English language journals.

The purpose of this article is to provide an analysis of the current state of higher education journals and their development to date (mid 2017). To do so I will first clarify what I mean by higher education journals, and indicate some of the range in existence. Then I will attempt to estimate how many there currently are, and discuss their varied characteristics. Finally, I will offer some further thoughts on their role and contribution to higher education research.

\section{Definitions and Range}

Even when we focus solely on refereed academic journals published in the English language, this still leaves a considerable number and diversity of journals to examine. For a start, we may recognise a threefold division between journals that focus exclusively on higher education research, those that regularly publish reports of 
higher education research, and those that occasionally do so (we will not consider the last of these further, as they do not represent a very fruitful target for higher education researchers seeking publication).

Journals that focus exclusively on higher education - typically, but not invariably, indicated by the inclusion of the words 'higher education' in their titles - may be divided into a further three types:

- First, there are what we might term generic journals (e.g. Higher Education Research and Development, Journal of Higher Education, Research in Higher Education), which, in principle, appear open to publishing articles on any aspect of higher education.

- Second, there are topic-specific journals (e.g. Assessment and Evaluation in Higher Education, Christian Higher Education, Higher Education Policy, International Journal for Academic Development, Journal of Marketing in Higher Education, New Directions for Teaching and Learning), which limit themselves to a particular topic or group of topics. This limitation is usually indicated in their title, and also spelt out on the journal's web page in more detail.

- Third, there are discipline-specific journals (e.g. Arts and Humanities in Higher Education, Journal of English for Academic Purposes, Journal of Geography in Higher Education), which focus on higher education research in a particular discipline or group of disciplines. Again, this is usually indicated in their titles.

An alternative categorization would divide higher education journals into two groups: international and nation (or region) specific. This might be seen as a second dimension running across the threefold first dimension just outlined, but, in practice, all of the nation-specific journals identified appear generic in character, so they may simply be designated as a fourth type.

International journals (e.g. Higher Education, Studies in Higher Education) invite and encourage submissions from researchers based anywhere in the world. They include what would likely be regarded as the highest status higher education journals, but that is not to say that all international journals are high status, or vice-versa. Countryspecific journals (e.g. Canadian Journal of Higher Education, South African Journal of Higher Education) confine themselves wholly or largely to research carried out in, or related to, higher education in the country in question. The country concerned is typically, but not always, indicated in the title of the journal in question.

Interestingly, there appears to be something of a developmental trend for journals along the country-specific to international dimension (a kind of academic drift if you like). That is, journals often start out focused upon a 
particular country or region - or even institution - but open up to become international as they expand and become established.

There are also, however, countervailing tendencies; thus American-based journals, in particular, even though they may be very well-established and of high status, typically continue to focus exclusively, or near exclusively, on research carried out in, and related to, the USA (and perhaps Canada: see Shahjahan and Kezar 2013, Tight 2014). This focus may, or may not, be made explicit in the notes of guidance provided for authors.

A similar, but slightly extended, categorization may be applied to other journals that publish significant numbers of articles focused on higher education, but do not focus exclusively on it. This categorization recognises that most, but not all, such journals are educational journals - that is, they publish articles focusing on all levels or stages of education (primary, secondary, higher, etc):

- First, generic education journals (e.g. Asia Pacific Educational Review, Oxford Review of Education) publish research considering all aspects and all levels of education.

- Second, topic-specific education journals (e.g. International Journal of Education Management, Journal of Education Policy, Journal of Education and Work, Learning and Instruction, Qualitative Studies in Education) publish research on particular topics - typically indicated in their titles - concerning all levels of education.

- Third, discipline-specific education journals (e.g. Education Economics, International Journal of Science Education) focus on research on all levels of education in particular disciplines or groups of disciplines, with the discipline usually included in their titles.

- Fourth, there are numbers of non-education journals, focusing on other disciplines (e.g. British Journal of Psychology, Journal of Human Behavior in the Social Environment), which publish a significant number of articles dealing with higher education research (and educational research in general). These mainly focus on social science disciplines, such as business/management, psychology and sociology.

As with journals exclusively focused on higher education, we may also recognise a further, in this case a fifth, category of education and other journals that regularly publish articles on higher education but focus on a specific nation. 
There is, therefore, a potentially bewildering range of journals which publish higher education research. Anyone wishing to keep up-to-date with such research, even if they are focused on a particular topic and disciplinary area, needs to be open to examining articles published in a broad range of outlets. This is so even in an age of online databases and search engines, as these typically have less than fully comprehensive coverage.

To make the analysis that follows more manageable, as well as limiting it to refereed academic journals published in the English language, I am further limiting it to journals that focus exclusively on higher education. Such journals publish the bulk of good quality higher education research.

As will become apparent, however, this is still quite an extensive field for analysis.

\section{Numbers}

As the discussion so far may have suggested, the question as to how many higher education journals there are even if we confine ourselves to those published in the English language - is not easy to answer. There is no agreed and definitive list available, and, even if there were, it would need continual updating, as new journals are created every year while established journals occasionally shut down. Thus, in recent years both Higher Education in Europe and Higher Education Management and Policy have ceased publication.

In other cases, two or more journals amalgamate. A recent and extreme example is the case of Higher Education Pedagogies, formed in 2015 from the amalgamation of eight separate journals (Bioscience Education, Business and Management Education in Higher Education, Engineering Education, Enhancing Learning in the Social Sciences, Health and Social Care Education, Innovation in Teaching and Learning in Information and Computer Sciences, Journal for Education in the Built Environment and Planet) set up by the Higher Education Academy in the UK between 2001 and 2014 as discipline-specific higher education journals. Clearly, there was not sufficient interest to sustain all of them in the longer term. It is also common for journals to change their names - as their focus or coverage develops, or as fashions and terminology changes - which can make them difficult to track.

Nonetheless, some have tried to compile a list of higher education journals. Thus, Bassett and Rumbley (2006, pp. 283-309; an updated version is available on the Center for International Higher Education's website: www.bc.edu/research/cihe/resources.html) listed 123 journals on higher education, of which 80 were English language publications. However, their list includes some journals which were not wholly focused on higher 
education, and some which were popular or professional (and thus most likely non-refereed), rather than academic, in orientation.

In a previous publication (Tight 2012a, pp. 229-232) I listed 53 academic journals focusing on higher education; while, in research for a forthcoming book (Tight 2018), which attempts to synthesize the research to date on higher education, in the extensive list of references I noted that some 140 journals were referenced on two or more occasions. Since the latter, however, included many journals that were not focused on higher education, I have used the former list, suitably updated, as the basis for the list of 86 higher education journals included in Table 1. In essence, the methodology adopted has been a simple one; to keep my wits about me, and to note down the title every time I got wind of a new journal or one I had not come across before, and then go to its website for further details.

\section{[Table 1 about here]}

I would not claim that the list in Table 1 is wholly comprehensive: how could it be? I am almost certain to have missed some journals; particularly, perhaps, newer ones available only online, and housed in a relatively obscure institution. The academic publication world is fairly volatile, with new journals being created all the time, particularly now in online and open access format. But the 86 journals identified in Table 1 offer a good basis for assessing the contemporary state of higher education research.

\section{Characteristics}

This section will review and compare the key characteristics of the 86 higher education journals identified, including their focus, ownership, location, orientation, age, size and ranking. In doing so, a useful picture should emerge of aspects of the organization and presentation of higher education research.

Editors sometimes carry out analyses of their own journals' output, and readers are referred to these for more detailed, journal-specific analyses:

- Dobson (2009) examined the Journal of Higher Education Policy and Management;

- Huisman (2008) discussed Higher Education Policy; 
- Ross (1992) considered Higher Education;

- Tight (2011) assessed Studies in Higher Education; and

- Volkwein, Carbone and Volkwein (1988) looked at Research in Higher Education.

Other authors have conducted comparative analyses of the outputs of a limited number of higher education journals, particularly, but not exclusively, in the American context (e.g. Budd and Magnusson 2010, Donaldson and Townsend 2007, Haggis 2009, Hart and Metcalfe 2010), and often focusing on a particular topic or theme.

\section{Focus}

Interestingly, the majority of the 86 journals identified in Table 1 (55, or 64\%) focus on a specific topic, theme or sector. Forty-nine of these journals focus on a topic or theme, while the remaining six focus on a particular sector.

Thus, in the former case, there are one or more journals focusing on each of the following themes - academic or faculty development, academic ethics, assessment, computing, continuing higher education, diversity, doctoral studies, educational technology, engagement, evaluation, the first-year experience, innovation, institutional research, international students, the internet, law, learning, management, marketing, method, outreach, pedagogy, planning, policy, practice, problem-based learning, public scholarship, publishing, quality, research, service learning, skills, student affairs, student development, student retention, success, sustainability, teaching, theory, women, work-based learning - as they impact upon higher education. In the latter case, we find journals focused on community colleges (two of them) and Catholic, Christian, Jesuit and Hispanic higher education.

By comparison, generic (14), discipline-focused (13) and nation-focused (4) higher education journals are rather less common. The discipline-focused journals are, though, of particular interest, as they contain - as we shall see - some of the oldest and most influential higher education journals. Even with the demise, noted earlier, of eight Higher Education Academy sponsored discipline-focused journals, the 13 journals that remain cover a rich variety of disciplines, including: accounting, art, design and communication, arts and humanities, economics, English, geography, health sciences, hospitality, leisure, sport and tourism, languages, management, medicine and neuroscience. 


\section{Ownership}

Many of the 86 journals are owned by, or closely linked to, learned societies, which established them as outlets for their members' and others' research. For example, Begg (1995), it's first editor, makes it clear that Tertiary Education and Management was established to publish a selection of the papers presented at the annual conference or forum of its owner society, the European Association for Institutional Research (EAIR). The journal has, however - as they usually do - moved on from this role, and is now open to articles from any source.

Just under half, 37 journals or $43 \%$, were of this kind, owned by 33 different societies. Three societies - the USbased Association for Institutional Research (AIR; from which the EAIR may be regarded as an offshoot) and Student Affairs Administrators in Higher Education (NASPA - which was for a time called the National Association of Student Personnel Administrators, hence the continuing acronym), with two each, and the UK-based Society for Research into Higher Education (SRHE), with three - owned more than one journal.

The same proportion, 37 journals or $43 \%$, are owned by their publishers, with 11 different publishers involved. Of these, Taylor \& Francis (11 journals, or 13\% of the total), Springer (7), Elsevier (5), Sage (4), Emerald (3) and Wiley (2) were the most prominent. Five journals were owned by their university, while for another seven (mainly recently established online journals) it was not possible to determine ownership.

\section{Location and Orientation}

Many of these journals, even though their focus may be international, remain firmly based in particular countries typically the major English-speaking nations of the USA, the UK, Australia and Canada. Others have become, or started off as, international in both operation and focus.

Thus, Higher Education was unusual in starting off with an explicit international mission; as its first, UK-based, editor expressed it: 'Higher Education intends to draw contributions from all parts of the world and thus become a truly international journal' (Ross 1972, p. 3). Two other examples may be given of journal's which started out with a narrower focus, but eventually became international. Becher, first editor of Studies in Higher Education, offered the somewhat gnomic advice that 'this journal's emphasis will be on a more modest level of generality, based on a greater abundance of evidence' (1976, p. 1), while Muffet and Massaro, first editors of the Journal of Higher 
Education Policy and Management (then called the Journal of Tertiary Education Administration), stated the fairly self-evident: 'This journal is intended for people interested in the administration of tertiary education' (1979, p. 4).

In terms of country of origin, $35(41 \%)$ of the journals were initially established in the USA, with 24 (28\%) starting life in the UK, five in Australia, four in Canada, and one each in five different other countries. For 13 of the journals it was not possible to identify a country of origin.

If we look instead at where the editors of the journals are based, a variety of patterns may be observed, ranging from single editors through dual editors, in the same or different countries, up to editorial teams of several people spread throughout the world. Currently, 34 (40\%) of the editorships (whether single or dual) are based in the USA, $18(21 \%)$ in the UK, four in Canada, three in Australia, two in South Africa, and one each in Belgium and Denmark, with 12 split between two countries, and eight (which we might term 'international') split between three or more countries. For three of the journals it was not possible to determine editorial location.

A third indicator of the 'nationality' of a journal is the make-up of the editorial board, which helps to determine the journal's geographic orientation. A substantial minority, 33 (38\%), were entirely composed of academics based in one country; most of these, 28 (33\% of the total), were comprised solely of US-based academics. A slightly larger number, $38(44 \%)$ had international editorial boards, with members drawn from several countries or more. The remaining 15 journals had what might be called 'split' editorial boards, with a substantial number of members based in one country and the remainder distributed across the rest of the world.

These patterns suggest two broad approaches, confirming the findings on national 'silos' for higher education research (Shahjahan and Kezar 2013, Tight 2014). On the one hand, many journals were established in and remain focused on the USA: $41 \%$ of the journals were established there, $40 \%$ have wholly US-based editors and $33 \%$ wholly US-based editorial boards. On the other hand, higher education journals established in the rest of the world have tended to become international over time.

We may speculate upon the reasons for these patterns. The American higher education system was the first to massify, resulting in both greater interest in researching it and more data to research. As we have seen, a disproportionate number of the earliest established higher education journals were US-based. The USA also had for a long time the largest system of higher education (this title now belongs to China), and it has its own particular nature, so there is plenty for American higher education researchers to study at home. 
By contrast, journals established outside of North America were based in smaller systems with fewer higher education researchers, so looking outside of the home system - including to the USA - for comparable research and potential authors was natural. While some UK-based and Australia-based journals were initially resistant, most have now become international in orientation. In countries where English is not the first language, but where publication in English came to be seen as crucial, regional links - as within Europe or the Asia Pacific region, for example - were important in establishing internationally oriented journals.

\section{Age}

The oldest of the journals identified, Academic Medicine, started publication in 1926, followed by the first generic higher education journal, the Journal of Higher Education, in 1930, and the first to be founded outside of the USA, Higher Education Quarterly, in 1947. In the USA, College Teaching and the Journal of Continuing Higher Education followed in 1953, and the Journal of College Student Development in 1959, with the first Australian higher education journal, the Australian Universities Review, established in 1958.

The 1970s were when higher education research publishing really took off, with 16 new journals founded in that decade (that have survived until the present time), more than doubling the number then published to 30 . Nine more higher education journals were added in the 1980s, and a further 13 in the 1990s. In this century, the field has expanded again, with 34 (or $40 \%$ ) of the journals identified in Table 1 having been founded since the year 2000.

The peak year to date was 2002, when seven new higher education that still survive were launched: Art, Design and Communication in Higher Education, Arts and Humanities in Higher Education, Christian Higher Education, Journal of English for Academic Purposes, Journal of Hispanic Higher Education, Journal of Hospitality, Leisure, Sport and Tourism Education and Journal of Undergraduate Neuroscience Education.

It should not be forgotten, however, that at least a dozen higher education, including some that were notably successful and built up a strong reputation, have also discontinued publication over this period, while others have amalgamated and lost their original identity. It is difficult, though, to be precise about the numbers of journals involved, as when something ceases to exist it is much more difficult to track down information about it. 
Size

The 'biggest' of the journals identified, in terms of volume of publication, was Studies in Higher Education, which published 2286 pages in 2016. It was followed by Academic Medicine, with 1707 pages, and Higher Education with 1646. While there are much bigger journals in some other disciplines, notably in the sciences, these are, by most standards, substantial volumes of publication, well beyond the capacity of most editors to cope with on their own.

In all, 12 of the journals published more than 1000 pages of articles in 2016 - the others were Higher Education Research and Development (1323), Assessment and Evaluation in Higher Education (1285), Medical Education (1283), Advances in Health Sciences Education (1136), Community College Journal of Research and Practice (1090), Journal of International Students (1078), Journal of College Student Development (1066), Research in Higher Education (1030) and Teaching in Higher Education (1021) - which indicates something about the scale of higher education research.

At the other end of the scale, the output of some journals was quite modest: for example, Excellence in Higher Education produced just 70 pages, while Student Success managed 76 pages and Jesuit Higher Education 88 pages. These journals were typically recently established, and sometimes highly specialised, so the former, at least, will likely expand in the future if they survive the initial period and prosper.

\section{Ranking}

Size is, of course, not everything; some smaller journals may be more selective, publish more influential articles and accrue greater status. A number of alternative journal ranking systems are available, including International Scientific Indexing (ISI), which ranks selected journals in terms of their impact factor (i.e. the relative number of times their articles are cited by others). Here, however, I have made use of the SCImago Journal Rank Indicator (www.scimagojr.com/journalrank.php), which compares a broader range of journals, again in terms of their relative citation rates.

Of the journals listed in Table 1, 54 (63\%) were ranked by SCImago. The highest ranked was one of the specialist journals, Internet and Higher Education, which had a rank of 3.561 for articles published in 2015 . It was followed by Academic Medicine (2.202), and then three generic higher education journals which were very similarly ranked: Research in Higher Education (1.724), Higher Education (1.717) and the Review of Higher Education (1.703). 
Eight other journals - Journal of Studies in International Education (1.564), Medical Education (1.55), Advances in Health Sciences Education (1.397), Journal of Higher Education (1.189), Journal of English for Academic Purposes (1.164), Studies in Higher Education (1.160), Active Learning in Higher Education (1.099) and Higher Education Quarterly (1.081) - had rankings in excess of 1.0 .

As suggested, the 13 highest ranked higher education journals are something of a mixed bunch. In terms of age, they include both the oldest established journals (Academic Medicine, the Journal of Higher Education and Higher Education Quarterly) and some relatively new ones (the Journal of English for Academic Purposes, founded in 2002, Active Learning in Higher Education (2000) and Internet in Higher Education (1998)). In terms of size, they include both the largest (Studies in Higher Education, Academic Medicine and Higher Education) and some with a relatively small output (Active Learning in Higher Education (260 pages) and Internet and Higher Education (396 pages)). And, in terms of editorial board membership, they include seven that are international, three that are wholly American, and three that are split.

\section{Key Journals}

Three measures - of age (10 years old at least, to reflect an established journal), size (at least 200 pages published in 2016, to reflect demand) and ranking (a SCImago rank of at least 0.5, to reflect readership) - have been used to compile the list of 28 key journals in Table 2 . Other or additional criteria could, of course, have been used, but the table arguably provides a reasonable assessment of which are currently the most reputable higher education journals.

Significantly, the great majority, 10, of the 14 generic higher education journals identified in Table 1 feature in Table 2; with both topic-specific (14 out of 55) and discipline-specific (4 out of 13) journals featuring less prominently. Unsurprisingly, none of the four nation-specific journals identified makes the list.

Nevertheless, Table 2 does still identify discipline-specific journals which would more likely be read by, for example, medical educators (Academic Medicine, Medical Education) or linguists (Journal of English for Academic Purposes), that is, by researchers with an interest in higher education who remain based in their disciplines. They appear alongside generic higher education journals, such as Higher Education, Research in Higher Education and Studies in Higher Education, and topic-specific journals, such as Assessment and Evaluation in Higher Education, 
the Journal of Hispanic Higher Education and Quality in Higher Education, which are probably more likely to be read by higher education researchers who do not have a disciplinary base.

\section{[Table 2 about here]}

Interestingly, the clear majority of these key journals (19 out of 28 , or $68 \%$ ) are international in their orientation, despite originating from and being based in the UK, Australia or another country. Five remain wholly US-focused, with the remaining four split between a focus on the USA, or in one case on Canada, and an increasing international orientation.

\section{Contribution}

Higher education research is an expanding field, and the growth in both the numbers and size of higher education journals reflects this (Tight 2012b). Thus, Higher Education, which began in 1972 publishing four (rather slimmer) issues a year, now publishes 12 issues a year in two volumes. Studies in Higher Education, to take a more extreme example, which started in 1976, was publishing only 2 issues a year up until 1986, but now publishes 12 . Interestingly, the US-based and focused journals do not appear to have gone through a period of such rapid expansion, so much of the recent growth in higher education research and publication has taken place outside of the USA.

The 86 journals identified in Table 1 between them published well over 40,000 pages of articles in 2016 . If we assume an average of 400 words per printed page, that amounts to around 16 million words! That is far more than any one individual could presume to 'read' in a year, even if they had nothing else to do, and this total is expanding year on year.

Higher education journals are clearly, therefore, making a massive contribution to higher education research. Of course, all of the articles published in all of the journals cannot be of the highest quality. Many will be repeating analyses that have already been carried out elsewhere in a different context, and adding only a limited amount to the sum of knowledge about higher education. Most are also relatively small-scale, focusing on a single case or a small number of cases (e.g. of students, courses, departments, institutions or nations). 
We would be on safe ground, however, to claim that higher education is fast becoming a well-researched field. It is no longer the case - as it was, for example, when I first got involved in higher education research nearly 40 years ago - that a new entrant to the field can start work with no special training and 'pick things up as they go along', quickly becoming familiar with the work of the (then limited number of) main players in their area.

That is not to say, of course, that all topics within the field have now received equal or adequate attention, or that there is not more to be done. Higher education itself is fast developing, and new topics needing research crop up every year. Improvements in practice and policy are still needed and possible, and will require careful evaluation. There is much still to be learnt from how things are done in other departments, institutions or nations.

Arguably, however, we now know a great deal about 'what works?' in higher education, whether we are talking about, for example, teaching and learning, institutional management or system policy. On most topics there is a significant amount of accumulated research of relevance which can usefully be consulted; though practitioners and policy-makers often appear reluctant to consult it.

Perhaps, therefore, the most pressing need in higher education research now is not to undertake more research as such, but to synthesise and learn the lessons from all of the research that has been done to date through systematic reviews and meta-analyses (Tight 2018). Then we will be able to move forward in a much more informed way. 


\section{References}

Bassett, R, and Rumbley, L (2006) Journals in Higher Education: an international inventory. In Altbach, P, Bozeman, L, Janashia, N, and Rumbley, L, Higher Education: a worldwide inventory of centers and programs. Chestnut Hill, MA, Centre for International Higher Education, Boston College, pp. 283-333.

Becher, T (1976) Editorial. Studies in Higher Education, 1, 1, pp. 1-2.

Begg, R (1995) Editorial. Tertiary Education and Management, 1, 1, pp. 5-6.

Budd, J, and Magnusson, L (2010) Higher Education Literature Revisited: citation patterns examined. Research in Higher Education, 51, pp. 294-304.

Dobson, I (2009) The Journal of Higher Education Policy and Management: an output analysis. Journal of Higher Education Policy and Management, 31, 1, pp. 3-15.

Donaldson, J, and Townsend, B (2007) Higher Education Journals' Discourse about Adult Undergraduate Students. Journal of Higher Education, 78, 1, pp. 27-50.

Haggis, T (2009) What Have We Been Thinking Of? A critical overview of 40 years of student learning research in higher education. Studies in Higher Education, 34, 4, pp. 377-390.

Hart, J, and Metcalfe, A (2010) Whose Web of Knowledge is it Anyway? Citing Feminist Research in the Field of Higher Education. Journal of Higher Education, 81, 2, pp. 140-163.

Huisman, J (2008) Higher Education Policy: the evolution of a journal. Higher Education Policy, 21, 2, pp. 265274.

Muffet, D, and Massaro, V (1979) Editorial. Journal of Tertiary Education Administration, 1, 1, p. 4.

Ross, A (1972) Editorial. Higher Education, 1, 1, pp. 3-5.

Ross, A (1992) Two Decades of Higher Education. Higher Education, 23, pp. 99-112.

Shahjahan, R, and Kezar, A (2013) Beyond the 'National Container'. Educational Research, 42, 1, $20-29$. 
Tight, M (2011) Eleven Years of Studies in Higher Education. Studies in Higher Education, 36, 1, pp. 1-6.

Tight, M (2012a) Researching Higher Education. Maidenhead, Open University Press, second edition.

Tight, M (2012b) Higher Education Research 2000-2010: changing journal publication patterns. Higher Education Research and Development, 31, 5, pp. 723-740.

Tight, M (2014) Working in Separate Silos? What citation patterns reveal about higher education research internationally. Higher Education, 68, 3, pp. 379-395.

Tight, M (2018) Higher Education Research: the developing field. London, Bloomsbury (forthcoming).

Volkwein, J, Carbone, D, and Volkwein, E (1988) Research in Higher Education: fifteen years of scholarship. Research in Higher Education, 28, 3, pp. 271-280. 
Table 1: Higher Education Journals

Generic (14)

European Journal of Higher Education; Higher Education; Higher Education Quarterly; Higher Education Research and Development; Higher Education Review; Journal of Further and Higher Education; Journal of Higher Education; Journal of Studies in International Education; Minerva; New Directions for Higher Education; Research in Higher Education; Review of Higher Education; Studies in Higher Education; Tertiary Education and Management

\section{Topic-specific (55)}

Active Learning in Higher Education; Assessment and Evaluation in Higher Education; Christian Higher Education; College Student Affairs Journal; College Teaching; Community College Journal of Research and Practice; Community College Review; Higher Education Pedagogies; Higher Education Policy; Higher Education, Skills and Work-Based Learning; Industry and Higher Education; Innovations in Education and Teaching International; Innovative Higher Education; International Journal for Academic Development; International Journal of Doctoral Studies; International Journal of Educational Technology in Higher Education; International Journal of Higher Education Management; International Journal of Sustainability in Higher Education; Internet and Higher Education; Jesuit Higher Education; Journal about Women in Higher Education; Journal of Academic Ethics; Journal of Applied Research in Higher Education; Journal of Catholic Higher Education; Journal of College and University Law; Journal of College Student Development; Journal of College Student Retention; Journal of Computing in Higher Education; Journal of Continuing Higher Education; Journal of Diversity in Higher Education; Journal of Faculty Development; Journal of Higher Education Outreach and Engagement; Journal of Higher Education Policy and Management; Journal of Higher Education Theory and Practice; Journal of Hispanic Higher Education; Journal of International Students; Journal of Learning Development in Higher Education; Journal of Marketing for Higher Education; Journal of Problem-Based Learning in Higher Education; Journal of Public Scholarship in Higher Education; Journal of Scholarly Publishing; Journal of Service Learning in Higher Education; Journal of Student Affairs Research and Practice; Journal of the First-Year Experience and Students in Transition; New Directions for Institutional 
Research; New Directions for Teaching and Learning; Perspectives: policy and practice in higher education; Planning for Higher Education; Policy Reviews in Higher Education; Quality in Higher Education; Research Evaluation; Student Success; Teaching and Learning Inquiry; Teaching in Higher Education; Theory and Method in Higher Education Research

\section{Discipline-specific (13)}

Academic Medicine; Accounting Education; Advances in Health Sciences Education; Art, Design and Communication in Higher Education; Arts and Humanities in Higher Education; International Journal of Management Education; International Review of Economics Education; Journal of English for Academic Purposes; Journal of Geography in Higher Education; Journal of Hospitality, Leisure, Sport and Tourism Education; Journal of Undergraduate Neuroscience Education; Language Learning in Higher Education; Medical Education

\section{Nation-specific (4)}

Australian Universities Review; Canadian Journal of Higher Education; Excellence in Higher Education [Indonesia]; South African Journal of Higher Education 
Table 2: Key Higher Education Journals

\begin{tabular}{|c|c|c|c|c|}
\hline Journal & Pages & Ranking & First Published & Orientation \\
\hline Academic Medicine & 1707 & 2.202 & 1926 & USA \\
\hline Accounting Education & 656 & 0.655 & 1992 & International \\
\hline Active Learning in Higher Education & 260 & 1.099 & 2000 & International \\
\hline Advances in Health Sciences Education & 1136 & 1.397 & 1996 & Canada/International \\
\hline $\begin{array}{l}\text { Assessment and Evaluation in Higher } \\
\text { Education }\end{array}$ & 1285 & 0.972 & 1975 & International \\
\hline Community College Review & 341 & 0.799 & 1973 & USA \\
\hline Higher Education & 1646 & 1.717 & 1972 & International \\
\hline Higher Education Policy & 554 & 0.681 & 1988 & International \\
\hline Higher Education Quarterly & 448 & 1.081 & 1947 & International \\
\hline Higher Education Research and Development & 1323 & 0.936 & 1982 & International \\
\hline International Journal of Doctoral Studies & 486 & 0.584 & 2006 & International \\
\hline $\begin{array}{l}\text { International Journal of Sustainability in } \\
\text { Higher Education }\end{array}$ & 894 & 0.616 & 2000 & International \\
\hline
\end{tabular}




\begin{tabular}{|c|c|c|c|c|}
\hline Internet and Higher Education & 396 & 3.561 & 1998 & USA/international \\
\hline Journal of College Student Development & 1066 & 0.615 & 1959 & USA/international \\
\hline Journal of English for Academic Purposes & 568 & 1.164 & 2002 & International \\
\hline Journal of Higher Education & 928 & 1.189 & 1930 & USA \\
\hline $\begin{array}{l}\text { Journal of Higher Education Policy and } \\
\text { Management }\end{array}$ & 689 & 0.525 & 1979 & International \\
\hline Journal of Hispanic Higher Education & 385 & 0.610 & 2002 & USA \\
\hline Journal of Studies in International Education & 487 & 1.564 & 1997 & International \\
\hline Medical Education & 1283 & 1.550 & 1966 & International \\
\hline Minerva & 490 & 0.658 & 1962 & International \\
\hline Quality in Higher Education & 276 & 0.652 & 1995 & International \\
\hline Research Evaluation & 495 & 0.919 & 1991 & International \\
\hline Research in Higher Education & 1030 & 1.724 & 1973 & USA/international \\
\hline Review of Higher Education & 504 & 1.703 & 1977 & USA \\
\hline Studies in Higher Education & 2286 & 1.160 & 1976 & International \\
\hline Teaching in Higher Education & 1021 & 0.802 & 1996 & International \\
\hline Tertiary Education and Management & 389 & 0.918 & 1995 & International \\
\hline
\end{tabular}


Notes:

Pages - number of printed pages published in 2016

Ranking - SCImago Journal Rank Indicator 2015

Orientation - Whether the editorial board international, wholly drawn from one country or split between one country and an international composition. 